
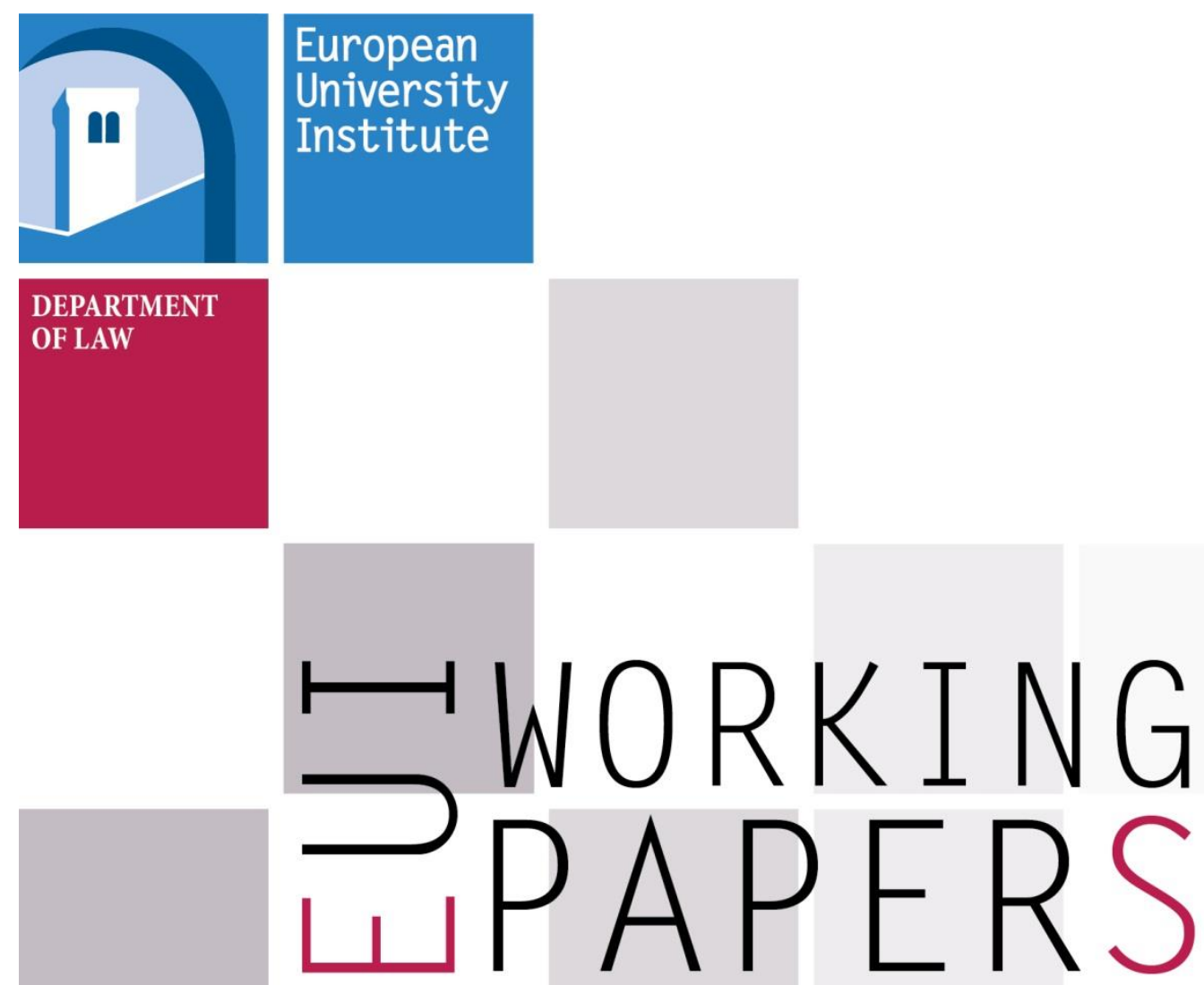

LAW 2020/15

Department of Law

A proposal for a Kantian definition of terrorism: Leading the world requires cosmopolitan ethos

Martin Scheinin 

European University Institute Department of Law

\section{A Proposal for a Kantian DeFinition of TERRorism: LEADING THE WORLD REQUIRES COSMOPOLITAN ETHOS}

Martin Scheinin

EUI Working Paper LAW 2020/15 
This text may be downloaded for personal research purposes only. Any additional reproduction for other purposes, whether in hard copy or electronically, requires the consent of the author, editor. If cited or quoted, reference should be made to the full name of the author, editor, the title, the working paper or other series, the year, and the publisher.

ISSN 1725-6739

(C) Martin Scheinin, 2020

Printed in Italy

European University Institute

Badia Fiesolana

I-50014 San Domenico di Fiesole (FI)

Italy

www.eui.eu

cadmus.eui.eu 


\begin{abstract}
This paper builds upon three streams of experience by its author: (a) one related to his six-year term as the first UN Special Rapporteur on human rights and counter-terrorism (2005-2011), namely the identification of the absence of a proper international definition of terrorism as an important source of human rights abuses, (b) his observation of actual court practice and media coverage where definitionalconceptual elements of terrorism, in particular as to its aims, appear to be ignored despite being one of the cornerstones on which those legal definitions were built, and (c) his academic work having concluded that the instrumentalization of the human person, in breach of Immanuel Kant's categorical imperative, comes through as a characteristic both of acts of terrorism and of human rights violations committed by States in the name of countering terrorism.
\end{abstract}

On the basis of reflecting on these experiences, and departing from his own best practice definition built on Security Council Resolution 1566 (2004) and included in his final report to the UN Human Rights Council, the author now proposes the removal of any subjective aim element from international definitions of terrorism, and its replacement with the objective element of the act amounting to the instrumentalization of human beings, typically victims of terrorism.

\title{
Keywords
}

cosmopolitan ethos; human dignity; human security; Immanuel Kant; legality; legitimacy; Security Council; Special Rapporteur (on human rights and counter-terrorism); terrorism (definition of) 


\title{
Author contact details:
}

\author{
Martin Scheinin \\ Department of Law \\ European University Institute \\ Villa Salviati (Castello), Via Bolognese 156, 50139 Florence, Italy \\ martin.scheinin@eui.eu
}

\section{Preface}

Legal scholars, political scientists and philosophers all struggle with the concept of terrorism. The challenges are not smaller for governments, prosecutors or judges that seek to apply the term as one of positive law. International organizations, in turn, are caught between a quest for legality and a need for consensus when seeking to mobilize the international community into effective action to combat international terrorism.

This Working Paper presents a new approach to defining terrorism in international and national law. It dispels the myth that there would be no legal definition of terrorism. Rather, what is here identified as the actual problem is that existing definitions have failed in catching the proper characteristics of terrorism, resulting in that those definitions may often be disregarded, circumvented or misused.

The definition of terrorism proposed in this paper is inspired by Immanuel Kant's ethics that today call for a cosmopolitan ethos from anyone who wishes to lead the world. The paper is currently being reviewed by the editors (Kim Lane Scheppele and Arianna Vedaschi) of a forthcoming volume on '9/11 and the Rise of Global Counter-Terrorism Law. How the UN Security Council Rules the World', towards submission to Cambridge University Press for publication. As per usual practice, this Working Paper version is intended for personal research purposes only. Comments by email to the author are of course warmly welcomed.

Today's $75^{\text {th }}$ anniversary of the entry into force of the United Nations Charter, and thereby the creation of the Security Council with genuine supranational powers, provides a perfect occasion to state, as this paper seeks to do, that whoever wishes to rule, lead or govern the world needs to be inspired by a cosmopolitan ethos.

Florence, 24 October 2020,

Martin Scheinin

martin.scheinin@eui.eu

Part-time professor, European University Institute

British Academy Global Professor, University of Oxford 


\section{Table of contents}

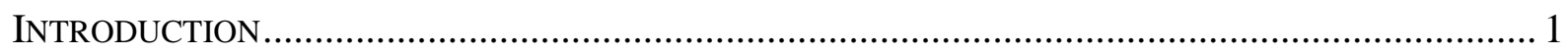

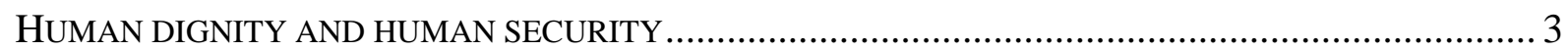

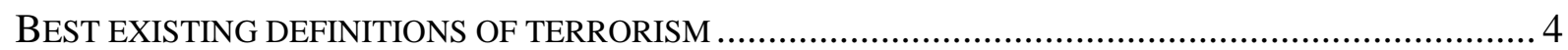

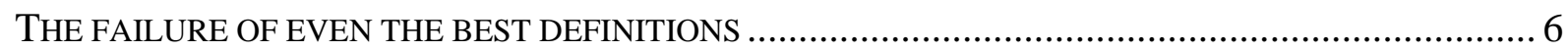

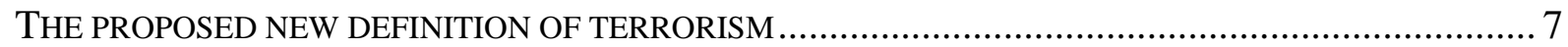

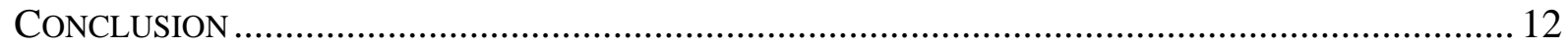





\section{Introduction}

While the UN Security Council has generally been at center stage in directing responses to $21^{\text {st }}$ century international terrorism, including through its questionable expansion of its own legislative powers, its role in defining terrorism has remained limited. This primarily passive approach has not been without problems. By requiring States to take decisive action against 'terrorism' while not making clear what terrorism is, the Security Council has in fact encouraged abusive and human-rights-hostile policies where individual States may use whatever means they have to go after political opposition, trade unions, or religious, ethnic, separatist or indigenous minorities, by stigmatizing them as terrorists. These abusive policies have thereby been shielded by the political clout provided by the Security Council. Fifteen years ago, this was a central tenet in this author's very first substantive report as the first United Nations Special Rapporteur on the promotion and protection of human rights and fundamental freedoms while countering terrorism:

Of particular concern to the Special Rapporteur's mandate is that repeated calls by the international community for action to eliminate terrorism, in the absence of a universal and comprehensive definition of the term, may give rise to adverse consequences for human rights. Calls by the international community to combat terrorism, without defining the term, can be understood as leaving it to individual States to define what is meant by the term. This carries the potential for unintended human rights abuses and even the deliberate misuse of the term. Besides situations where some States resort to the deliberate misuse of the term, the Special Rapporteur is also concerned about the more frequent adoption in domestic anti-terrorism legislation of terminology that is not properly confined to the countering of terrorism. Furthermore, there is a risk that the international community's use of the notion of "terrorism", without defining the term, results in the unintentional international legitimization of conduct undertaken by oppressive regimes, through delivering the message that the international community wants strong action against "terrorism" however defined. ${ }^{1}$

In an effort to promote approaches based on the rule of law and compliance with human rights, this author, in my capacity as Special Rapporteur (2005-2011), systematically assessed the counter-terrorism law and practice of individual States through their definitions of terrorism, judged against the requirement of legality in criminal law, as enshrined in the non-derogable provision of Article 15 of the International Covenant on Civil and Political Rights (ICCPR). I promoted narrow and precise definitions and built my scrutiny of national laws on existing definitions or elements of definitions in international law, including Security Council Resolution 1566 (2004) $)^{2}$ which did come close to defining what terrorism is, which was unusual for the Security Council's otherwise passive approach to the matter. I urged the Security Council and its subordinate bodies, including the Counter-terrorism Committee, the terrorist Sanctions Committees and the Counter-terrorism Executive Directorate, not only to push States to fight against terrorism as defined by themselves but to do so by focusing on actual terrorism amounting to a threat to international peace and security, instead of targeting their own dissidents and minorities. As a culmination of this line of work, the author's final report as Special Rapporteur, ${ }^{3}$ considered by the Human Rights Council in 2011, presented ten elements of best practice in combating terrorism, one of them being a model definition of terrorism.

This paper builds upon three streams of experiences encountered by its author: (a) one related to my sixyear term as the first UN Special Rapporteur on human rights and counter-terrorism, culminating in a

1 Report of the Special Rapporteur on the promotion and protection of human rights and fundamental freedoms while countering terrorism, Martin Scheinin, UN document E/CN.4/2006/98, para. 27.

2 UN Security Council Resolution 1566 Concerning Threats to International Peace and Security Caused by Terrorism, S/RES/1566 (2004).

3 UN Human Rights Council: Report of the Special Rapporteur on the promotion and protection of human rights and fundamental freedoms while countering terrorism, Martin Scheinin: Ten areas of best practices in countering terrorism, UN Doc. A/HRC/16/51. 
best practice definition of terrorism based on the multitude of international efforts to characterize terrorism and aimed at curtailing abusive or opportunistic terrorism definitions by oppressive regimes; (b) observation of actual court practice and media coverage where definitional-conceptual elements of terrorism, in particular as to its aims, appear to be lost, in part because of not corresponding to common sense or intuition; and (c) academic work by myself and others, pointing out that instrumentalization of the human person, in breach of Immanuel Kant's categorical imperative, comes through to a disturbing level as a characteristic both of acts of terrorism and of non-strategic or bad faith counter-terrorism measures by States.

On the basis of my reflection on these experiences and now departing from the best practice definition I included in a 2011 report to the UN Human Rights Council, I propose here the removal of any subjective aim element from international definitions of terrorism, and its replacement with the objectively verifiable element of instrumentalizing human beings, who often are innocent bystanders that end up as victims of lethally violent acts of terrorism as a consequence of an intentional choice or pure ignorance by the perpetrators.

In the original Preface to his book The Future of Human Rights, Upendra Baxi noted how work for human rights sometimes emerges as Herculean, while at other times it resembles the ordeals of Sisyphus. ${ }^{4}$ Indeed, many experiences as Special Rapporteur on human rights and counter-terrorism represented the metaphor of Sisyphus who spends his every day pushing a heavy stone uphill to the top of a mountain; only to find it at its bottom again next morning. Human rights appeal to morality and reason, also in the context of countering terrorism because compliance with human rights would enhance the sustainable effectiveness of counter-terrorism efforts while at the same time reducing ensuing human rights harms. Nevertheless, every time there is a new terrorist attack, politicians may resort to the instinct of doing 'everything' and at any cost and thereby set aside human rights. Insisting on proper definitions of terrorism or of terrorist crimes to comply with the legality requirement of ICCPR Article 15 was and remains a Sisyphean task. The correctness of such insistence has been acknowledged in professional counter-terrorism circles but in practice deviations from it have remained frequent. For the Security Council this most often has entailed, in its resolutions or review of States' counter-terrorism measures, urging States to take firm action against terrorism but leaving them free to retain their overbroad and abusive definitions of it.

My final report to the Human Rights Council, considered in 2011, presented ten areas of best practice in countering terrorism, one of them amounting to pushing the stone of defining terrorism one more time up onto the top of the mountain. The fairly technical, but uncompromisingly precise, formulation in that report reads:

\section{Practice 7. Model definition of terrorism}

Terrorism means an action or attempted action where:

1. The action:

(a) Constituted the intentional taking of hostages; or

(b) Is intended to cause death or serious bodily injury to one or more members of the general population or segments of it; or

(c) Involved lethal or serious physical violence against one or more members of the general population or segments of it; and

2. the action is done or attempted with the intention of:

(a) Provoking a state of terror in the general public or a segment of it; or

\footnotetext{
4 Upendra Baxi, The Future of Human Rights, Oxford University Press 2002, p. viii. There is a briefer reference to Sisyphus in the Preface to the third edition, in the context of human rights as resistance, see Upendra Baxi, The Future of Human Rights (third edition), Oxford University Press 2008, p. xvii.
} 
(b) Compelling a Government or international organization to do or abstain from doing something; and

3. The action corresponds to:

(a) the definition of a serious offence in national law, enacted for the purpose of complying with international conventions and protocols relating to terrorism or with resolutions of the Security Council relating to terrorism; or

(b) All elements of a serious crime defined by national law. ${ }^{5}$

Now, almost ten years later, the stone is again at the bottom of the mountain. My two successors as Special Rapporteur and many others, have continued the work of Sisyphus without hesitation, ${ }^{6}$ but all too often the Security Council, national governments, or even prosecutors or judges do not appear to care about how international and national law actually defines terrorism, or about proof beyond reasonable doubt for affirming that every element of the applicable legal definition was met. Rather, the word terrorism carries a strong stigma of moral and legal condemnation, to the degree that if it is even mentioned, then the law no longer matters. Depicting someone as a terrorist suffices to legitimize the denial of their human rights or a departure from the 'technicalities' of the law. Journalists and members of the general audience tend not to understand what the problem is. What is worse, they probably would not even accept if judges were to care about how the law actually defines terrorism. In the eyes of the public, terrorism is perceived of as political violence for an unjustified cause, or even as 'crimes committed by Muslims'.

Existing definitions of terrorism have failed not only the test of legality but also the test of public legitimacy. These would be pragmatic reasons why those definitions should be reconsidered. More importantly, there are also principled reasons, even foundational moral reasons, for saying that even the best definitions of terrorism have failed and will continue to fail. Besides not meeting the tests of legitimacy or evidentiary expedience, they also are faulty at deeper levels because of being at the same time casuistic and under-inclusive, and because of, for political reasons, both missing some important elements of the phenomenon of modern-day terrorism and being ambiguous and thereby open to differing and even abusive interpretations.

In this paper, a proposal therefore is made for a new definition of terrorism, for purposes of international and domestic law.

\section{Human dignity and human security}

In an earlier book contribution, ${ }^{7}$ I explored the relationship between security and human dignity through proposing to redefine the former with a focus on human security, i.e. the security of people, human beings, rather than of States. If counter-terrorism measures are being justified as necessary means to protect security, and if it is argued that sometimes security must trump the human rights of an individual - such as a suspected terrorist -- then one must both insist on the uncompromised protection of the human dignity of everyone - again including the suspected terrorist - and humanize the understanding of security. Security considerations may legitimately justify some restrictions of human rights - but never their all-things-considered violations, but only if also the security discourse, through its

5 UN Doc. A/HRC/16/51 (see, footnote 3, above), Best Practice No. 7, para. 28.

6 See, for instance, Report of the Special Rapporteur on the promotion and protection of human rights and fundamental freedoms while countering terrorism, Ben Emmerson, UN document A/HRC/31/65 (2016), para. 35; Report of the Special Rapporteur on the promotion and protection of human rights and fundamental freedoms while countering terrorism, Fionnuala Ní Aoláin, UN document A/HRC/40/52 (2019), para. 19.

7 Martin Scheinin, Human Dignity, Human Security, Terrorism and Counter-Terrorism, in Christophe Paulussen and Martin Scheinin (eds.) Human Dignity and Human Security in Times of Terrorism, T.M.C.Asser Press 2020. 
humanization, actually passes the test of legitimacy in the meaning of being capable of meeting general acceptance by the people.

That earlier contribution addressed the fact that for human rights scholars and other human rights actors, the notion of human dignity carries a strong positive connotation as a background value of all human rights, while references to 'security' are often approached with caution and suspicion. Relying upon Immanuel Kant's appeal to reason and his formulation of the categorical imperative as a maxim that any rational person must never treat another human being as mere means but always also as an end, ${ }^{8}$ the article presented human dignity in exactly that context of treating every person as an end, and called for the application of the same test in the security discourse. Instead of being viewed as a threat to human rights, the notion of security will require a nuanced treatment when addressed in a human rights perspective. When every person is treated as an end, then all references to security will be placed in the framework of respecting human rights, resulting in a paradigm of human security. Notably, this would not be a different approach than what we are used to in respect of the notion of 'dignity' which also has its dark - nationalist or even fascist - side and actually only merits its usual positive connotation because of the systematic inclusion of the qualifier 'human'. Security also has many facets in the vernacular of human rights, ranging from an individual right to security to the right to social security and to a recognized legitimate aim for restricting some human rights, often qualified as national or public security.

As explained in that earlier essay, a discourse on human security has acquired a place in United Nations documents and policies, ${ }^{9}$ even if often forgotten by the counter-terrorism actors. And even within counter-terrorism, some of the documents with the most lasting impact, such as the 2006 Global Counter-Terrorism Strategy adopted by the General Assembly, are reflective of a human security approach. Of particular value in this context is so-called Pillar I of the strategy, on addressing and eliminating 'conditions conducive' to terrorism (i.e., its 'root causes') that can be seen as a relatively early affirmation and application of the human security approach in counter-terrorism. ${ }^{10}$

That contribution closes with some reflections on how both terrorism and counter-terrorism may suffer of the same moral failure of reducing individuals - victims or perpetrators of terrorism - to mere means and not always treated also as ends. Terrorists often reduce their victims to mere means by using them as an instrument to create horror or to blackmail governments. Responses by States all too often in their responses exacerbate the moral failure by denying the humanity of the suspected terrorists and in themselves treating them as mere means. Through these reflections, my earlier contribution forms a first part in a Kantian effort to redefine terrorism. What the reader now has in front of her constitutes the second and final part. Before presenting a new Kantian definition of terrorism, let us however take a look at best existing definitions of terrorism and their failures.

\section{Best existing definitions of terrorism}

In this Section, some examples of relatively good efforts to define terrorism in international instruments are presented. The author's own model definition, cited above in Section 1, was based on these and some other treaties or resolutions that in the author's view represent good faith efforts in defining terrorism or acts of terrorism in a manner that respects the requirement of legality and thereby also human rights. The model definition itself, proposed as best practice, is not repeated here.

8 Immanuel Kant, The Fundamental Principles of the Metaphysics of Morals, trans. T. K. Abbott, vol. 1 (New York: Prometheus Books, 1987 [1785]), page 57.

9 UN General Assembly (2012) Follow-up to General Assembly resolution 64/291 on human security: Report of the SecretaryGeneral, UN Doc. A/66/763 (2012).

10 Plan of Action in UN General Assembly (2006) Resolution adopted by the General Assembly on 8 September 2006, UN Doc. A/RES/60/288, Annex, Section I, para 1. 
Firstly, there are more than twenty international treaties or protocols that, for the purpose of defining their own scope of application, contain an explicit or implicit set of conditions for treating an act as terrorism. At global (United Nations) level, these treaties ${ }^{11}$ range from the 1979 Hostages Convention ${ }^{12}$ to the 1999 Terrorist Financing Convention. ${ }^{13}$ There are also Council of Europe treaties and an EU Counter-terrorism Directive ${ }^{14}$ (that was preceded by a Framework Decision) that belong to the same family of instruments. Three characteristics of these instruments are of significance here: (a) they provide fairly precise formulations of a small number of terrorist aims, usually two but in the case of the 1979 Hostages Convention only one and in the case of the EU Directive also a third - and highly problematic - one $;^{15}$ (b) many of them seek to preserve legality through the requirement that an act can be an act of terrorism only if it falls under a pre-existing treaty against terrorism (e.g., the 1999 Terrorism Financing Convention) or an exhaustive list of enumerated pre-existing crimes (the EU Directive); and (c) most of them address terrorism as acts or threats of deadly or otherwise serious violence against human beings.

Secondly, while the Security Council has, particularly after 9/11 of 2001 been a driver of international action against terrorism, often using its mandatory powers under Chapter VII of the UN Charter, in most cases it has not bothered to make clear what exactly needs to be countered when the Security Council urges States to take decisive action against terrorism. An exception - and therefore a positive exception - is Security Council Resolution 1566 of 2004. This resolution was adopted under Chapter VII and can thus legitimately be seen as an authentic interpretation of what the Security Council means when it in other Chapter VII resolutions has referred to terrorism or international terrorism. In operative paragraph 3 the Security Council provides a concept of terrorism that corresponds to the defining characteristics of good faith efforts to define terrorism in international treaties. It reads as follows:

3. Recalls that criminal acts, including against civilians, committed with the intent to cause death or serious bodily injury, or taking of hostages, with the purpose to provoke a state of terror in the general public or in a group of persons or particular persons, intimidate a population or compel a government or an international organization to do or to abstain from doing any act, which constitute offences within the scope of and as defined in the international conventions and protocols relating to terrorism, are under no circumstances justifiable by considerations of a political, philosophical, ideological, racial, ethnic, religious or other similar nature, and calls upon all States to prevent such acts and, if not prevented, to ensure that such acts are punished by penalties consistent with their grave nature;

The highlights in italics, added here by myself, are aimed at demonstrating the three defining characteristics identified earlier, here in the order of violent acts against persons (item c above), terrorist aims (item a above), and enumerated crimes (item $b$ above).

There are other, substantively similar, efforts to define terrorism in international law. In a 2011 ruling, the Appeals Chamber of the Special Tribunal for Lebanon sought to identify and formulate a norm of

11 For a list, see https://www.un.org/counterterrorism/international-legal-instruments.

12 International Convention Against the Taking of Hostages, UNTS 1316 p. 205. For definitional elements, see its Article 1.

13 International Convention for the Suppression of the Financing of Terrorism, UNTS vol. 2178 p. 197. For definitional elements, See Article 2.

14 Directive (EU) 2017 on combating terrorism and replacing Council Framework Decision 2002/475/JHA and amending Council Decision 2005/671/JHA, Official Journal of the European Union vol. 60 L 88/6. For defining elements of terrorist offences, see Article 3.

15 Article 3, para. 2 (c): "seriously destabilising or destroying the fundamental political, constitutional, economic or social structures of a country or an international organization". 
customary international law which in important respects echoes treaty law in the matter, in particular what comes to the aims of terrorist acts, labeled by the Tribunal as 'special intent'. ${ }^{16}$ It stated:

On the basis of treaties, UN resolutions and the legislative and judicial practice of States, there is convincing evidence that a customary rule of international law has evolved on terrorism in time of peace, requiring the following elements: (i) the intent (dolus) of the underlying crime and (ii) the special intent (dolus specialis) to spread fear or coerce authority; (iii) the commission of a criminal act, and (iv) that the terrorist act be transnational. ${ }^{17}$

As is evidenced here, and also was reflected in the Special Rapporteur's model definition of terrorism presented earlier, the actual problem no longer is that international law would not be able to provide a definition, or a whole family of mutually compatible definitions, of terrorism. Rather, my argument is that the problem is in the failures of those definitions themselves, both as a matter of principle, and as a matter of practice. This is where we will now turn.

\section{The failure of even the best definitions}

There are many ways how, or many reasons why, even the best existing international law definitions of terrorism have failed in delivering what they should, namely a device for prosecuting, trying and convicting the perpetrators of morally repulsive acts while at the same time respecting the rule of law, the requirement of legality in criminal law and the right to a fair trial. Some of the main reasons for these failures are mapped in this Section.

The casuistic nature of some existing definitions. As efforts towards a comprehensive convention against terrorism have failed, the now existing patchwork of international instruments has emerged through a series of coincidences, such as the occurrence of a specific terrorist act in a specific place at a specific time. As a result, the definitions are casuistic in nature, as exemplified by the prominent place of hostagetaking or civilian aircrafts in them.

Existing definitions result in evidentiary problems. As there has been so much focus in defining the aim (or purpose, or qualified intent) of the perpetrators of terrorist acts, the resulting formulations have proven difficult to apply in practice. As a result, the aim to 'terrorize' the population or to 'compel' a government to doing something will have to be inferred rather than proven. Prosecutors and even judges may rely on their general understanding of the phenomenon of terrorism, or international terrorism, or of a particular terrorist organization, in satisfying themselves that a proper terrorist aim has been proven to justify a conviction. The problem of lack of proof is particularly burning for anarchistic terrorism and for suicide terrorism, two categories for which actual evidence of the aim will be hard to obtain. Because of the tendency to resort to inferences, defining terrorism through its assumed terrorist aims will end up undermining the requirement of legality, rather than strengthen it.

There is a legitimacy problem. The typical approach of two alternative aims of terrorism also suffers of a legitimacy problem in the eyes of the general public, the media and politicians. When a heinous act of murdering innocent bystanders through an extremely violent attack has occurred, it does not strengthen the legitimacy of the law if prosecutors decide not to prosecute, or judges not to convict of terrorist crimes but, instead, of ordinary crimes because of the absence of a proven terrorist aim to create fear or to compel the government. The general public may accept that a lonely young person murdering dozens

\footnotetext{
16 Special Tribunal for Lebanon, Appeals Chamber: The Prosecutor v. Ayyash et al., Interlocutory Decision on the Applicable Law: Terrorism, Conspiracy, Homicide, Perpetration, Cumulative Charging ('Applicable Law'). Case No. STL-11-01/I of 16 February 2011.

17 Special Tribunal for Lebanon, STL Casebook: Major rulings issued by the Special Tribunal for Lebanon 2013, p. 33. Available at: https://www.stl-tsl.org/sites/default/files/documents/legal-documents/stl-casebooks/STL_Casebook_201_ EN.pdf.
} 
of his schoolmates with a semi-automatic gun, ${ }^{18}$ or even a frustrated airplane pilot intentionally crashing into a mountain ${ }^{19}$ acted because of problems in their personal life but will not accept the same conclusion if the perpetrator were to fit the public's (unfounded) perceptions of who might be a terrorist.

The absence of a reference to an ideology is counter-intuitive. Journalists, politicians and members of the general population associate terrorism with fundamentalist religious, political or other ideologies. When legal definitions, prosecutors or courts do not address the ideological inspirations of the crimes in question, this further weakens the legitimacy of the law and of its application in the eyes of the public. The ideological leanings of the alleged perpetrators may also become an intransparent aspect of the trial, not addressed openly but referred to through proxies or in code. The fairness of the trial may be at risk. Here, it is worth noting that Security Council Resolution 1566 (2004) is more transparent on this point, as it includes the phrase that acts meeting the definition of terrorism "are under no circumstances justifiable by considerations of a political, philosophical, ideological, racial, ethnic, religious or other similar nature".

The definitions are not strictly applied in practice. What may result from the above-listed problems in the application of existing terrorism definitions, is that some of their elements are simply disregarded by prosecutors or judges, causing a problem of legality. Convictions for terrorism may become crimes of association in the sense that any proven expression of sympathy for a terrorist organization, such as nowadays ISIS, becomes a proxy for determining that the perpetrator had the aim of creating fear amongst the general population or, for instance, if the country has military forces in the Middle East, the aim of compelling the government to withdraw its troops. What was intended as a good faith effort to maintain the requirement of legality in criminal law, deteriorates into its opposite. In the worst case, the practice of prosecutors or judges may resemble the caricature of the rule of law, the phrase "terrorism is crimes committed by Muslims".

Existing definitions are not based on a proper moral principle. While the failures of the existing definitions of terrorism listed above are many and on their own alarming, they are still secondary in comparison to a more important failure, namely that even the best international law definitions of terrorism do not spell out the moral principle on which they are founded. Here, we need to turn to Immanuel Kant and the absence from existing definitions of the distinguishing characteristic of acts of terrorism to instrumentalize other persons - typically innocent bystanders - by reducing them to mere means.

\section{The proposed new definition of terrorism}

The multiple pragmatic reasons why even the best existing definitions of terrorism have failed may not be sufficient to justify that they should be scrapped to give room for a new one. What is more important is the final point in the above list, namely that the existing definitions do not explicate their underlying broader moral principle. My claim is that the principle is already implied but has not found a proper expression in the existing formulations. What makes terrorism a particularly morally repulsive subcategory of political violence and of crimes, is the instrumentalization of innocent bystanders who are not the actual target of the act but who are reduced to mere means for the perpetrator, for whom the actual aspirations lie elsewhere than in killing or maiming those particular individuals who become victims of terrorism.

18 See, Report by the Virginia Tech Review Panel 2007, https://www.webcitation.org/6QK80tA35?url =https://web.archive.org/web/20131015095917/http://www.governor.virginia.gov/TempContent/techPanelReport-docs/F ullReport.pdf.

19 See, Martin Scheinin, Was the Crash of Germanwings Flight 9525 an Act of Terrorism? Just Security (blog) 2015, https://www.justsecurity.org/21649/crash-germanwings-flight-9525-act-terrorism/. 
Immanuel Kant famously insisted on a strict separation between rational beings (human persons) and all other objects (things). One of his formulations of the categorical imperative reads:

For all rational beings come under the law that each of them must treat itself and all others never merely as means, but in every case at the same time as ends in themselves. ${ }^{20}$

It is possible to capture this moral principle in a legal definition of terrorism. Doing so would address some of the more pragmatic reasons for the failure of existing definitions. Therefore, it is now high time to make the proposal, which is presented in full below:

Terrorism means an intentional action or attempted action where, irrespective of whether the action is committed in furtherance of a political, ideological, religious or comparable aim:

1. The action amounts to the instrumentalization of one or more human persons by reducing them to mere means in the commission of the act through:

(a) the taking of hostages; or

(b) the use of physical violence that causes or is intended to cause death or serious bodily injury to one or more persons in their capacity as members of the general population or segments of it; and

2. The action corresponds to:

(a) the definition of a serious offence in national law, enacted for the purpose of complying with international conventions and protocols relating to terrorism or with resolutions of the United Nations Security Council relating to terrorism; or

(b) all elements of a serious crime defined by national law.

This full version has been written as if it were a provision of a national Penal Code but it could also be included in an international treaty or a resolution by the Security Council. It seeks to be in full compliance with the requirement of legality in criminal law, including through its item 2 that restricts the application of the notion of terrorism to pre-existing criminal law provisions that must either have their basis in international counter-terrorism instruments or otherwise be identified in national law as serious crimes. Item 1 of the proposed definition has much in common with best existing terrorism definitions, including Security Council Resolution 1566 and the Special Rapporteur's best practice definition. Hostage-taking (sub-item a) would still be recognized as a specific form of terrorism, representing a paradigmatic case of instrumentalizing and reducing a human being to mere means, irrespective of whether actual death threats are made because hostage-taking is taken as inherently lifethreatening to the victim. Otherwise the actus reus (sub-item b of item 1) is defined through serious physical violence to human persons, either because of actually causing death or serious bodily injury, or because of an intent or attempt to cause such a consequence. Further, the chapeau of the whole definition emphasizes the required intentional nature of acts that will be regarded as terrorism. All these elements are well-established and traditional in best existing definitions of terrorism.

As an aside, it deserves to be mentioned that Immanuel Kant's categorical imperative not only provides the basis for a definition of terrorism based on the universal moral rejection of reducing any human person to mere means but also serves, through the force of logic, as a valid reason to exclude from the definition of terrorism crimes causing even extensive damage to property, but not harming or aimed at harming humans:

The worth of any object which is to be acquired by our action is always conditional. Beings whose existence depends not on our will but on nature's, have nevertheless, if they are irrational beings, only a relative value as means, and are therefore called things; rational beings, on the contrary, are called persons, because their very nature points them out as ends in themselves, that is as something which must not be used merely as means,.$^{21}$

20 Kant 1987 [1785] (see, footnote 8, above), p. 62.

21 Ibid., p. 57. 
The remaining part of the chapeau amounts to a clarification rather than an element of a strict conceptual definition. It is included in part as a response to the pragmatic considerations presented earlier and not as an expression of a higher moral principle. Prosecutors and judges will be seeking guidance as to whether a specific ideological or comparable aim needs to be established and proven beyond reasonable doubt before someone can be convicted of terrorism. The chapeau makes clear that the answer is negative: a proven ideological or comparable aim is not a sine qua non for a terrorism conviction. As it neither is a decisive and sufficient element for treating certain conduct as an act of terrorism, the chapeau makes it clear that even if such an aim often is typical for terrorism, proving its presence will not be sufficient. Instead, the true requirements for conviction are the preceding reference to an intentional act (general mens rea) and the subsequent items 1 and 2 that are cumulative in nature, i.e. must both be met in order to arrive at a conviction.

Where the proposed definition breaks new ground is the introductory phrase in item 1 and the resulting deletion of other elements that may be found in existing definitions of terrorism. Those deleted elements would typically be related to specific terrorist aims, such as to compel a government to specific action or to create fear (terror) amongst the general population. Such qualified forms of intentionality (specific mens rea) are no doubt typical for many acts of terrorism. Quite often, and in particular in cases of suicide terrorism, they will however be difficult or impossible to prove and will in practice, therefore, need to be constructed by the prosecutor and the judge. Thereby they lose their value as defining conceptual elements of the notion of terrorism. By dropping the requirement of specific terrorist aims and instead focusing on the objectively assessed instrumentalization of one or more human beings as mere means, the proposed definition would compel the prosecutors to prove what can be proven, instead of simply assuming something, by demonstrating how the objective circumstances of the crime amounted to the instrumentalization of the victims. The assessment would be based on the perspective of an objective external observer as to whether the act amounted to the instrumentalization of the victims, i.e., to their reduction to mere means, instead of speculatively constructing an aim for the perpetrator. While the assessment would still be constructed, it would be openly so, similar to the wellrecognized culpability standard for intentional crimes: the perpetrator knew or should have known that his actions will cause the death of other persons.

By placing the element of instrumentalization center stage in the definition of terrorism the proposed definition captures the essence of terrorism as compared to other forms of crime or political violence. Through this restructuring of terrorism definitions, the proposal acknowledges and restates as law the underlying moral principle for the universal and unconditional condemnation of terrorism as a distinct category of repulsive acts.

Would the proposed definition have any practical consequences, by altering the scope of acts that are regarded as terrorism? I believe that it would greatly reduce the risk of erroneous application of the stigma of terrorism to acts that should be treated as ordinary crimes, even if committed by a person who fits stereotypical perceptions about who the 'usual suspects' of terrorism are. It would also make it more clear than existing definitions that atrocious acts committed by members of the mainstream population, either out of hatred for minorities or for peaceful protesters, or simply in the hope of attracting 'fifteen minutes of fame' should in some cases be treated as terrorism. One would need to zoom out from their subjective motivations and refocus on an external assessment whether the act entailed the instrumentalization of others.

The proposed definition would also include as terrorism acts falling under Hannah Arendt's notion of radical evil, used by her to distinguish the crimes of the Nazi regime from even most horrendous regular crimes committed by individuals. In one of her letters, she seeks to address what makes radical evil different, suggesting that it is worse than simply reducing human beings to one's own means to an end, whatever that end might be:

What radical evil is I don't know, but it seems to me it somehow has to do with the following phenomenon: making human beings as human beings superfluous (not using them as means to an 
end, which leaves their essence as humans untouched and impinges only on their human dignity: rather, making them superfluous as human beings). ${ }^{22}$

In an earlier letter, Arendt had described the Nazi crimes as "an organized attempt... to eradicate the concept of the human being" ${ }^{23}$ Remarkably, Arendt also paved the way for a universal and cosmopolitan ethos, insisting that "human dignity needs a new guarantee which can be found only in a new political principle, in a new law on earth, whose validity this time must comprehend the whole of humanity". ${ }^{24}$ While individual States will also in the future need to define terrorist crimes in their Penal Codes, we may need the international community, including through the UN the Security Council, to proclaim the principle.

A short version of my proposed definition, suitable for journalistic, political or educational discourse, would focus on item 1 in the full definition, and reads as follows:

Terrorism is deadly or otherwise serious physical violence against members of the general population or segments of it (bystanders) that amounts to their instrumentalization, i.e. their reduction to mere means in the commission of the crime.

The proposed definition - both its full version and the short version - represents a Kantian approach in seeking to demonstrate the underlying moral principle for the universal condemnation of terrorism. Such universal condemnation is only possible if terrorism is distinguished from many other forms of political violence or serious crime through a universal moral principle. Unconditional rejection of the instrumentalization of another human being is here claimed to have that moral appeal. By basing the definition of terrorism upon it, the international community and States would find a solid moral basis for restoring public trust and the legitimacy of their counter-terrorism efforts. Rule of law would also win, as references to specific terrorist aims that very often are impossible to prove and will simply be ignored by prosecutors and judges would be deleted. Instead, the definition would refocus on what can be objectively assessed through a careful demonstration and analysis of the concrete facts in the individual case, namely that the act entailed the instrumentalization of the immediate victims of the crime to mere means in its commission.

Other academics have made commendable efforts to redefine terrorism, or to codify an international law definition thereof. Of note is in particular the definition proposed by Ben Saul. ${ }^{25}$ His definition also builds on existing international instruments on terrorism but does not convince the current author. In my view unnecessarily, he excludes acts committed as part of an armed conflict from the scope of terrorism. I see no reason for that, even if I do acknowledge that war crimes may often be easier to prove through objectively verified evidence than the defining element of instrumentalization that I am proposing. Because of this, there may often be a good pragmatic reason to prioritize war crimes prosecution. This is, however, a decision of prosecutorial strategy, and I see no problem in that there is an overlap in the scope of application of criminal law provisions on war crimes and terrorism as long as the requirement of ne bis in idem is respected, usually simply through the prosecutor having to make the choice.

Problematically, Saul includes "political, ideological, religious, or ethnic purpose" as a conceptual element of his definition of terrorism. In my view, the "irrespective of" formulation proposed here, as inspired by Security Council Resolution 1566 (2004) is a better option, as one avoids a potential unjustified reduction of the scope of application of the definition of terrorism. My most fundamental disagreement with Saul relates to his definition retaining the reference to the two traditional alternative

22 Hannah Arendt/Karl Jaspers correspondence, 1926-1969, edited by Lotte Köhler and Hans Saner (Robert Kimber \& Rita Kimber trans., Harcourt Brace Jovanovich Publishers 1992), p. 166: Letter dated 4 March 1951.

23 Ibid., p. 69: Letter dated 17 December 1946.

24 Hannah Arendt, The Origins of Totalitarianism (Benediction Classics. 2009 [1951]), ix.

25 Ben Saul, Defining Terrorism in International Law, Oxford Monographs in International Law (Oxford: Oxford University Press, 2008), pp. 65-66. 
aims/intents of terrorism, while the essence in my proposal is in replacing them altogether with the objectively assessed element of instrumentalizing human persons.

Another academic author who deserves attention here is Alex Schmid whose efforts to establish a definition of terrorism through finding academic consensus about its elements primarily reflect a political science, rather than international law, understanding of terrorism. He has produced both a short five-element version and a full sixteen-element version of the definition, of which the latter is presented here:

Terrorism is an [1] anxiety-inspiring method of repeated [2] violent action, employed by (semi-) [3] clandestine individual, group, or state actors, for [4] idiosyncratic, criminal, or political reasons, whereby - in contrast to assassination - the direct targets of violence are not the main targets. The [5] immediate human victims of violence are generally chosen [6] randomly (targets of opportunity) or [7] selectively (representative or symbolic targets) from a target population, and serve as message generators. [8] Threat- and violence-based [9] communication processes between terrorist (organization), (imperiled) victims, and main targets are used to [10] manipulate the main target (audience(s)), turning it into a [11] target of terror, a [12] target of demands, or a [13] target of attention, depending on whether [14] intimidation, [15] coercion, or [16] propaganda is primarily sought. ${ }^{26}$

What is remarkable here is how strongly the underlying moral principle of instrumentalizing human beings comes through in this list, even if it has never been made explicit in existing international law definitions of terrorism. Even if Schmid does not formulate that moral principle in Kantian terms, the phrases above presented in italics make a lot of sense in the context of the proposal made in this article and provide support for the new legal definition of terrorism proposed above. Schmid's choice of words such as 'randomly', 'symbolic targets', 'message generators', or 'are used... to manipulate', all placed in italics in the above quotation, make a compelling case for understanding instrumentalization of human persons as the essence of terrorism.

This paper would not be complete without a reference to the 2006 ruling of the German Constitutional Court concerning a law providing authorization to shoot down a civilian airplane if it was hijacked by terrorists to be used as a weapon in the manner of the terrorist attacks of 9/11 in the United States. The Court referred to the terrorists reducing the passengers of the aircraft to mere means but also unconditionally affirmed that the human dignity clause in the German Basic Law (Constitution) prohibits using their conduct as justification for an analogous reduction by the State of the passengers to mere means if legislation were to be approved that authorized the downing of the plane. Famously, the Court stated:

... the assumption that anyone who is held on board an aircraft under the command of persons who intend to use the aircraft as a weapon of a crime against other people's lives within the meaning of $\S 14.3$ of the Aviation Security Act has become part of a weapon and must bear being treated as such also does not justify a different assessment. This opinion expresses in a virtually undisguised manner that the victims of such an incident are no longer perceived as human beings but as part of an object, a view by which they themselves become objects. This cannot be reconciled with the Basic Law's concept of the human being and with the idea of the human being as a creature whose nature it is to exercise self-determination in freedom (see BVerfGE 45, 187 (227)), and who therefore may not be made a mere object of state action. ${ }^{27}$

\footnotetext{
26 Alex Schmid, "Terrorism - the Definitional Problem Symposium: Terrorism on Trial," Case Western Reserve Journal of International Law 36, no. Issues 2 \& 3 (2004): 382 (emphasis added).

27 German Constitutional Court, Judgment of the First Senate of 15 February: 1 Bvr 357/05 (2006), para 134.
} 


\section{Conclusion}

The human rights community, including the three consecutive holders of the mandate of the UN Special Rapporteur on the promotion and protection of human rights and fundamental freedoms while countering terrorism, have for two decades fought an uphill battle to constrain States in their use of the stigma of terrorism in overbroad or abusive ways and to insist on the requirement of legality in criminal law as a non-derogable human right. This uphill battle, or the task of Sisyphus who day after day pushes a heavy stone onto the top of the mountain even if knowing that during the night it will again roll down to its bottom, has time and again been frustrated by the ignorance of the law by many of the authorities whose task would be to apply it, often amounting to human rights violations.

This paper has proposed a new approach. Instead of only insisting on the full and proper application of best existing definitions of terrorism, the human rights community should lead the way towards new consensus based on a fundamental moral principle that allows for the identification of the essential reason why terrorism is universally morally repulsive. A new Kantian definition of terrorism was proposed, based on the universal moral rejection of the instrumentalization of another human person through her reduction to mere means instead of always treating her also as an end. Who wishes to rule - or, rather, govern - the world needs to represent and demonstrate cosmopolitan moral leadership. 
